\title{
健康人に発症した鼻脳型ムュール症例
}

$\begin{array}{lrrr}\text { 花満 } & \text { 雅一・坚玉 } & \text { 章・望月 } & \text { 隆* } \\ \text { 田中 } & \text { 寛・片岡 } & \text { 英幸・北嶋 } & \text { 和智 }\end{array}$

\section{A Case of Rhinocerebral Mucormycosis in a Normal Host}

\author{
Masakazu Hanamitsu, Akira Kodama, Takashi Mochizuki, \\ Hiroshi Tanaka, Hideyuki Kataoka and Kazutomo Kitajima \\ (Shiga University of Medical Science)
}

\begin{abstract}
Mucormycosis usually occurs in patients with diabetic acidosis or in immunosuppressive conditions such as malignant disease, steroid therapy or cytotoxic therapy. This paper describes our experience with rhinocerebral mucormycosis (RCM) in an apparently normal host, and an accompanying literature survey. A 68-year-old man was admitted because of pain in the right buccal region. Computerized tomography and magnetic resonance imaging revealed a shadow in the right maxillary sinus, which was expanding into his right orbit, cavernous sinus and middle cranial fossa, with signs of destruction of the ethmoidal and maxillary walls. His definite diagnosis was RCM, due to the detection of the genera Rhizopus by an open biopsy of his maxillary sinus. He was treated by debridement of the right pansinuses, and an intravascular administration of amphotericin $\mathrm{B}$ (AMPH). There was kidney dysfunction as a side effect of the AMPH, but a total dose of $899 \mathrm{mg}$ of AMPH was administered by discontinuation for a month and alternate-day therapy. He did not undergo orbital exenteration; he had normal visual acuity and ocular movement. There was no recurrence 18 months after the treatment.

$\mathrm{RCM}$ is a fatal disease, and the mortality rate is $38 \%$ even given a correct diagnosis and treatment. About $4.5 \%$ to $18 \%$ of $\mathrm{RCM}$ cases have no predisposing factors according to the literature. RCM in normal hosts has a lower mortality rate than in patients with diabetes, but early diagnosis and treatment are still imperative.
\end{abstract}

Key words : rhinocerebral mucormycosis, normal host, sinus, Rhizopus, amphotericin B

はじめに

近年, 鼻副鼻腔に発症する真菌症の報告例は増加して 扣り, 病原菌としては, アスペルギルスがもっとも多く ムコール，カンジダが続く1). 多くは予後良好であるが, その中でもムコールによるものは, 菌が血管壁を侵し浸 潤性に増殖するため，予後不良であることが多い．今回 我々は, 基礎疾患のない健康成人で副鼻腔より眼窩, 頭 蓋窩に進展した鼻脳型ムュール症を経験し，早期の確定
診断と治療により良好な結果を得ることができたので， 文献的考察を加光報告する.

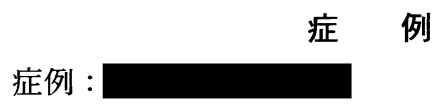

主訴：右頓部痛.

職業 :

嘹好歴：40年前より紙タバコ 1 日約18本. 
既往歴: 平成 5 年 胃潰瘍, 大腸ポリープを摘出. 平 成 6 年 氮径へルニア.

現病歴：平成 6 年 8 月より頭痛之右䫅部痛を自覚し, 近医で鎮痛剤の処方を受けていた。同年10月頃より右鼻 閉, 複視, 右眼痛が出現し右頓部痛も増悪した. 同年 10 月31日某院受診し，頭部 CT で，右上㴿洞に骨破壊を伴 ら陰影を認め, 同年11月 2 日当科紹介之なった。

初診時身体所見：右中鼻道に表面の一部が灰白色，表 面粗造の腫瘤を認めた。右眼球突出, 右三叉神経第 2 枝 領域の知覚鈍麻, 右眼の外転障害を認めた。他に神経症 状はなく，全身所見にも特に異常を認めなかった。

血液検查所見：CRP, 赤沈の上昇を認める以外特に免 疫系を含めて異常所見を認めなかった(表 1 ).

単純鼻X線所見(図 1 ): 右上顎洞, 右篩骨洞に陰影を 認め, 紙状板, 眼窩下壁が不鮮明化していた。

頭部 MRI 所見 (図 2)：T1 強調像で，上顎洞，穊骨 洞を中心に均一な低信号の陰影を認めた。それらは， Gd-DTPA にて一部造影効果を受け, さらに眼窩, 翼口 蓋窩, 中頭蓋窩, 海綿静脈洞へ進展していた。海綿静脈 洞付近で, 内頸動脈は flow void を認め, 左右対称であ ク，異常を認めなかった．T2強調像では，低信号，高 信号の部分が混在していた。

頭部 CT 所見(図 3)：MRI と同部位飞造影効果を受 ける陰影を認めた。眼窩内に進展する陰影により, 視神 経が上方へ圧排されていた。眼窩下神経に沿って高輝度 像があり，紙状板に所々，点状の骨欠損を認めた。

ガリウムシンチグラム所見：鼻部以外の集積なし。

以上の検査上り, 右上顎洞原発の悪性腫瘍を疑い, 中 鼻道の腫瘤より生検を行ったが，炎症所見のみであった ため，上頂洞試験開放を行った。上顎洞には膿を伴った

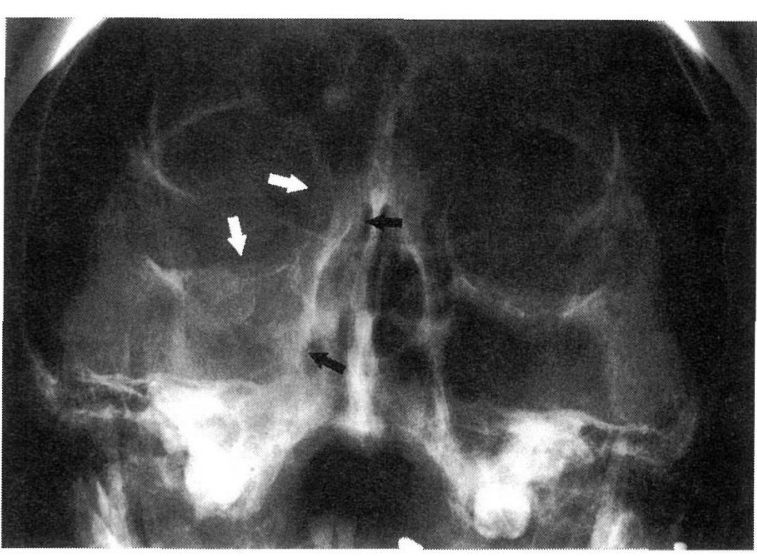

図 1 単純X線(ウォーターズ法)。右上顎洞, 右篩骨洞に陰影 （ヶ)を認め, 紙状板, 眼窩下壁が不鮮明化している (৬).

灰白色の乾酪様物質が存在していた. 検体の HE 染色 にて, 主に好酸球を中心とする多数の炎症細胞とその中 に，隔壁を持たない不規則にくびれた菌系を認め(図 4 A),ムコール症が疑われた。同時に施行した真菌培着 の結果，その形態よりムコール科 Rhizopus 属と同定さ れ(図 4B)，この菌による鼻脳型ムコール症(以下 $\mathrm{RCM}$ と略す) と確定診断した。

11月18日菌塊の進展範囲を考慮し, 全身麻酔下江右汎 副鼻腔根本術を行い，右上顎洞，笠骨洞，蝶形骨洞の乾 酪様菌塊を可及的に搔爬除去した。眼窩下壁は柔らかく 海綿様となっていた．菌塊を搔爬除去したが眼球も含め 眼窝内容は保存した。 上䫇洞内側壁は消失，下甲介骨も 前端を残して消失していた，術後アアンホテリシン $\mathrm{B}$ (以 下 AMPH と略す)による治療を開始した(図 5 )。ネビ ュライザーによる鼻腔よりの AMPH 吸入，濃度 100

表 1 血液検查

\begin{tabular}{ll|ll}
\hline \hline 赤血球 & 427 万 $/ \mathrm{mm}^{3}$ & リンパ球数 & $1516 / \mathrm{mm}^{3}$ \\
白血球 & $6800 / \mathrm{mm}^{3}$ & $\mathrm{IgG}$ & $2107 \mathrm{mg} / \mathrm{dl}$ \\
血小板 & $27.9 \times 10^{4} / \mathrm{mm}^{3}$ & $\mathrm{IgM}$ & $255 \mathrm{mg} / \mathrm{dl}$ \\
$\mathrm{CRP}$ & $1.3 \mathrm{mg} / \mathrm{dl}(\uparrow)$ & $\mathrm{IgA}$ & $376 \mathrm{mg} / \mathrm{dl}$ \\
赤沈 & $82 \mathrm{~mm}(1$ 時間 $)(\uparrow)$ & $\mathrm{C} 3$ & $81 \mathrm{mg} / \mathrm{dl}$ \\
空腹時血糖 & $88 \mathrm{mg} / \mathrm{dl}$ & $\mathrm{C} 4$ & $26 \mathrm{mg} / \mathrm{dl}$ \\
& & $\mathrm{CD} 3$ & $77 \%$ \\
肝機能 & 異常なし & $\mathrm{CD} 4$ & $59 \%$ \\
腎機能 & 異常なし & $\mathrm{CD} 8$ & $24 \%$ \\
& & $\mathrm{CD} 16$ & $14 \%$ \\
$\mathrm{SCC}$ & $1.1 \mathrm{ng} / \mathrm{ml}$ & $\mathrm{CD} 19$ & $13 \%$
\end{tabular}




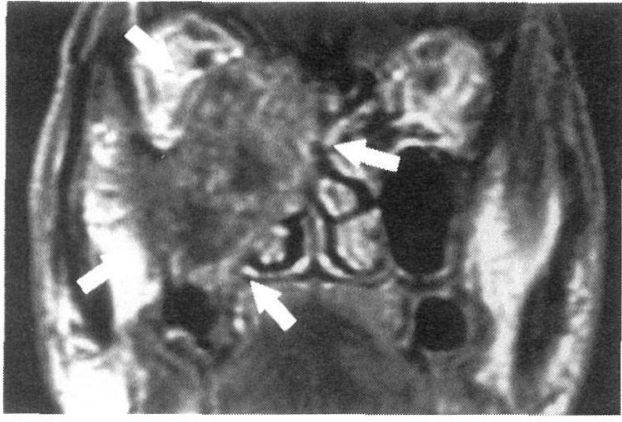

A

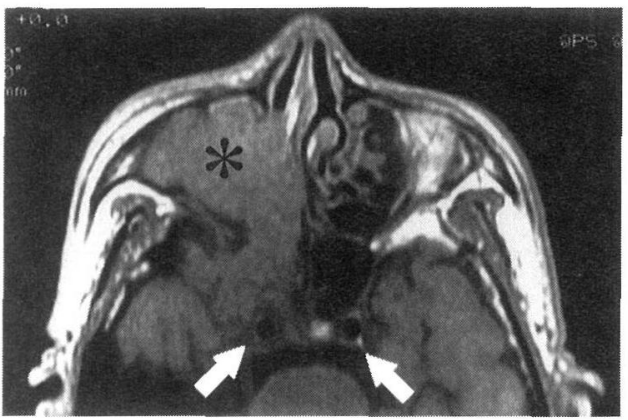

$\mathrm{C}$

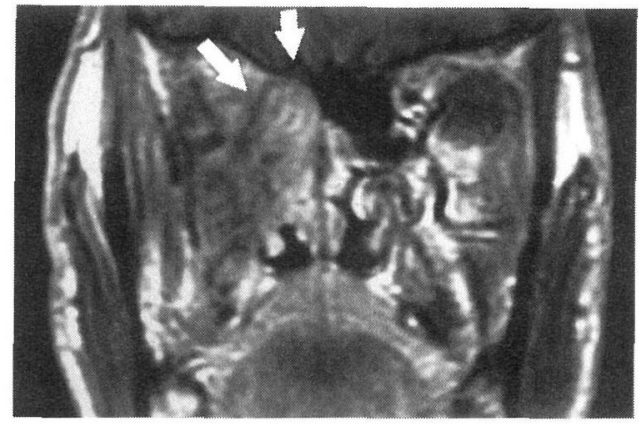

$\mathrm{B}$

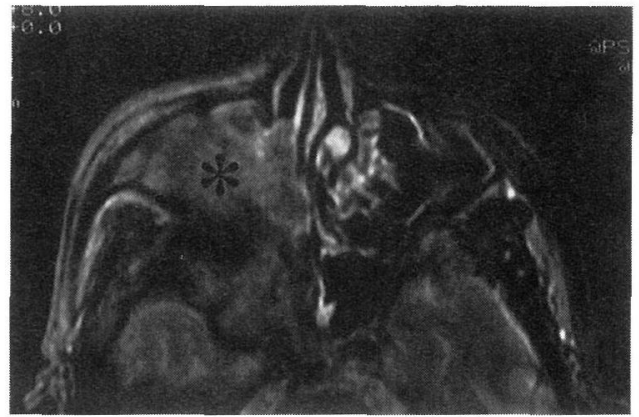

D

図 2 A. MRI 所見(T1 強調，Gd-DTPA 投与後)，上顎洞，穊骨洞，眼窩に造影される陰影(↔) を認める。

B．A と同条件．陰影は翼口蓋窩へ進展している(↔).

C. MRI 所見 (T1 強調)，中頭蓋窩，海綿静脈洞に進展する均一な低信号の陰影(*)を認め る.内頸動脈は flow voidを認め, 左右対称となっている (く).

D. MRI 所見 (T2 強調)。低信号, 高信号の部分が混在している(*).

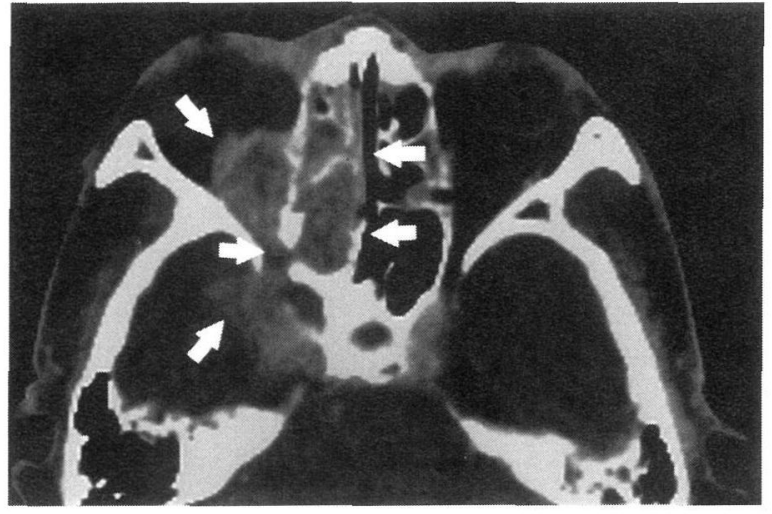

A

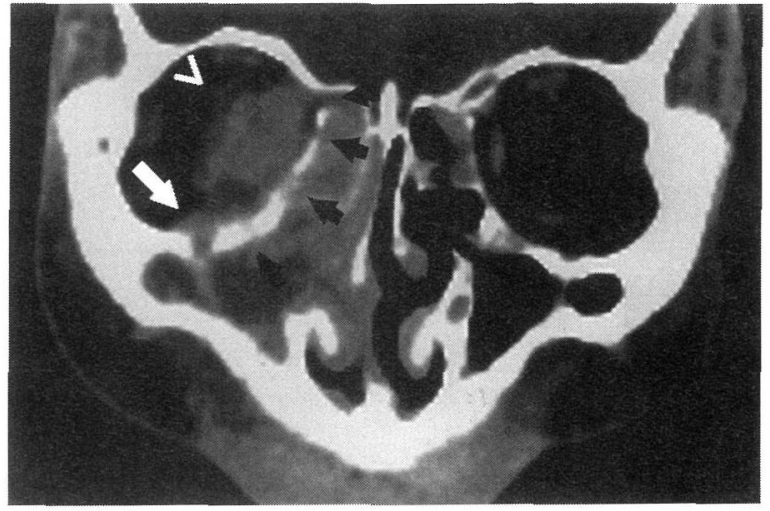

B

図 3 A. CT 所見(水平断, 造影後)。連続する陰影を認める(や)。

B. CT (冠状断, 造影後)。視神経が上方へ圧排されている $(V)$. 眼窩下神経に沿って高輝度像が, 上䕱洞から眼 窩内に存在している(๒). 紙状板に所々, 点状の骨欠損を認める 


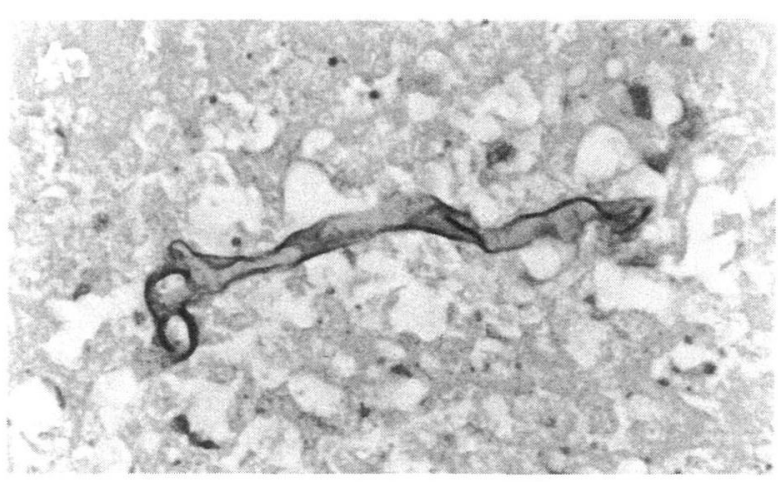

A

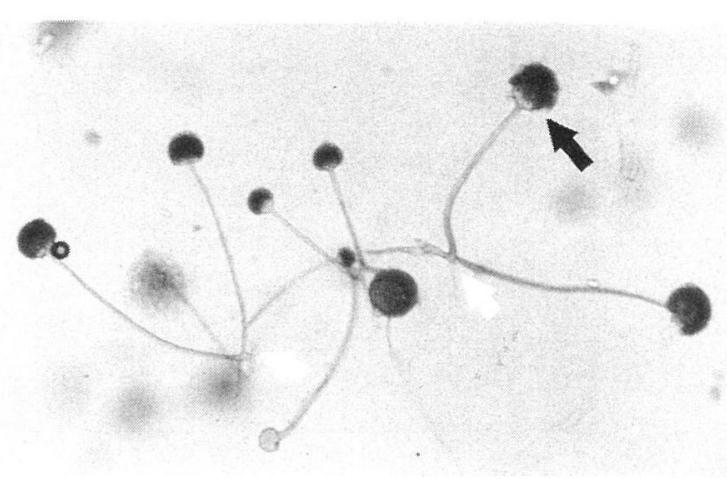

B

図 4 A. 組織所見 $(H E$ 染色，×400)。隔壁のない，不規則にくびれた菌糸を認める。

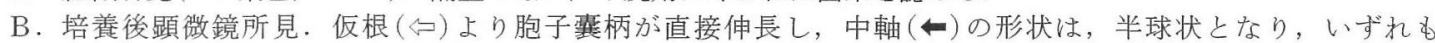
Rhizopus の特徴を示している.
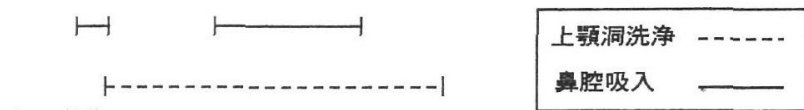

(mg/日)
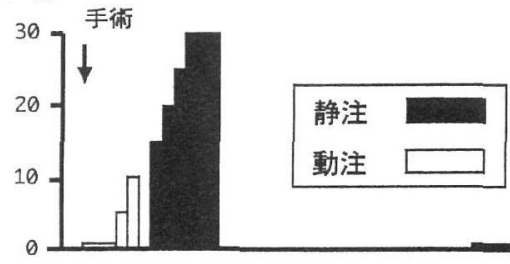

血液生化学検査

( $\mathrm{ml} /$ 分)
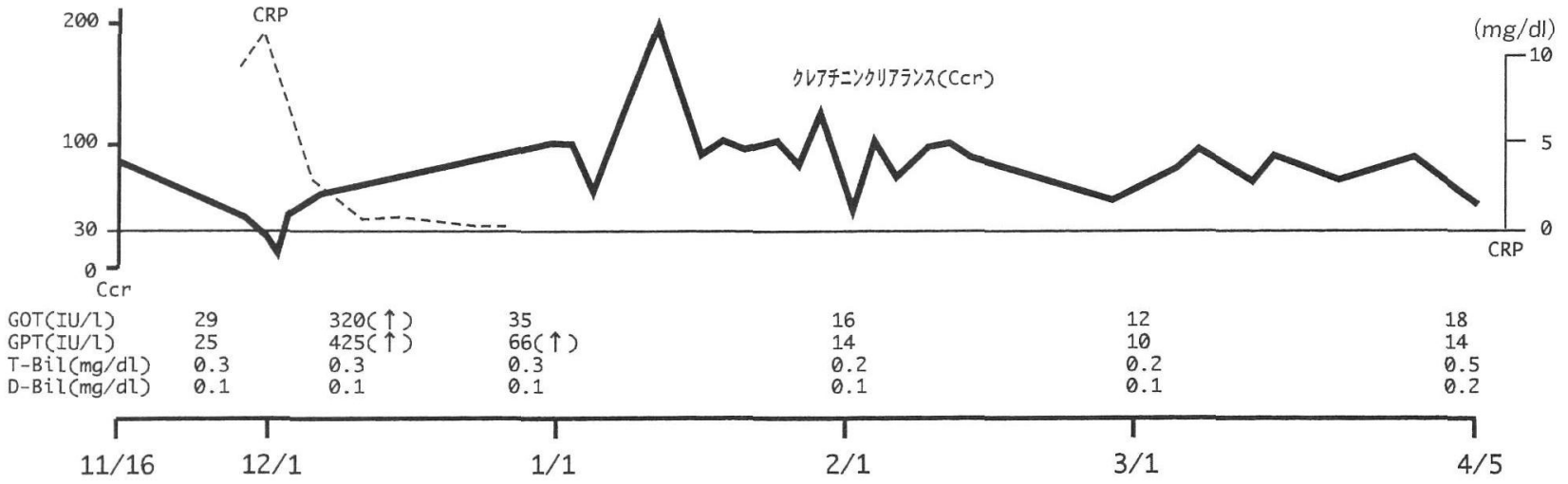

図 5 アンホテリシンBの使用経過

$\mu \mathrm{g} / \mathrm{ml}$ の $\mathrm{AMPH}$ 液による上顎洞洗浄, また, 浅側頭動 脈から逆行性に顎動脈分岐部に留置したカテーテルより AMPHの持続動注を11月18日より行った。しかし，持 続動注は血管痛が強く 1 日 $10 \mathrm{mg}$ 以上の投与は困難で
あったため，11月23日より持続静注とした。11月30日ま でに総量 $138 \mathrm{mg}$ の血管内投与を行ったが，クレアチニ ンクリアランスが $12 \mathrm{ml} /$ 分まで低下, GOT $320 \mathrm{IU} / 1$, GPT 425 IU/1，と腎障害，肝障害を認めたため静注を 
中止し，上顎洞洗浄だを12月18日まで行った。12月14 日には, 眼球運動改善, CRP 陰性化, 煩部痛の改善が 認められたが，MRIでは残存する陰影を認めたため， 腎，肝機能の回復を待って，再び静注を開始した。クレ アチニンクリアランスが低下すれば隔日で静注を続けた。 1 月25日には、コージメーターでも眼球運動に全く異常 を認めなくなり, 眼球突出も消失した。3 月31日, 髄液 検查正常，4月5日，鼻内所見で乾酥様菌塊や，炎症性 の粘膜は認められなくなり, 右三叉神経第 2 枝領域の知 覚鈍麻以外に異常な所見無く, MRI 上の残存する陰影 にも変化無いため, 治療終了とした。総量 $899 \mathrm{mg} の$ AMPH の血管内投与老行った. 治療終了後 1 年 3 力月 現在も変化を認めない(図6).

\section{考察}

ムコール症は正常の免疫能が働く健康人に発症するこ とは少なく, 白血病などの悪性疾患, ステロイドや抗癌 剤治療中，といった免疫機能の障害された患者や，ある いは糖尿病患者に発症する。糖尿病患者に認められるケ トアシドーシス下では, 白血球の貪食作用が減少した $り^{22}$ ，またRhizopus は, active keton-reductase system を持ち, low pH，高血糖下でも成長可能なことが糖尿病 患者がムコール症に陥りやすい理由と考光られている3゙. $\mathrm{RCM}$ は, 最初は副鼻腔に炎症巣を作り, 血管親和性に 前あるいは後篩骨動脈を介して眼窩内へ，さらに眼尖部 を経て頭蓋窩に進展するか，あるいは篩板を経て前頭蓋
窩へ進展し，さらに頭盍内の動脈に血栓を生じ梗塞を起 こし，急激な経過で死亡する予後不良の疾患である。炎 症が副鼻腔粘膜までに限局しているものは，非侵襲型 (non-invasive type) ${ }^{415)}$ にあたり，予後はよくほとえど基 礎疾患を有さない6)。しかし，先に述べたようなリスク を伴う場合, 洞内を越兄て眼窩, 頭蓋内に進展し, 予後 不良となると思われる，特に糖尿病を合併することが多 く, Blitzer ら ${ }^{7)}$ とよと $74 \%$, 本邦報告例(表 2 )でも $71 \%$ が糖尿病を基礎疾患として持っている。 しかし今回 の症例のようにはっきりした基礎疾患を持たない健康

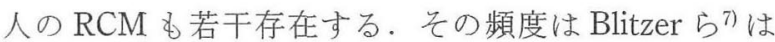

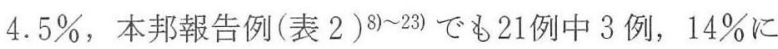
認められる。今回の症例では，患者は 10 年前より，中国 より輸入した竹を納屋でマスクをせずに加工して拈り， その際，竹についたかびを多量に吸っていたと証言して いることから，発症との関連が示唆された。他，職業上 菌体を吸入する機会が多く発症との関連が疑われた例之 して，久米ら ${ }^{24)}$ は上顎洞ムュール症の1例で，周囲に 多数のかびが付着する自家製の味䁚樽の手入れを 1 日 2 回していた例を報告している。

治療は原則として，糖尿病などの基礎疾患があればそ の治療を行い, AMPH の静注と副鼻腔根本術に準じて 壞死組織を含めた菌塊の除去を行う。必要であれば，眼 球も摘出する。ムコール症に効果がある抗真菌剤として は，1955年に開発された AMPH 以外，確実にその有効 性が証明されているものは現在でもない，吸入，洗浄用

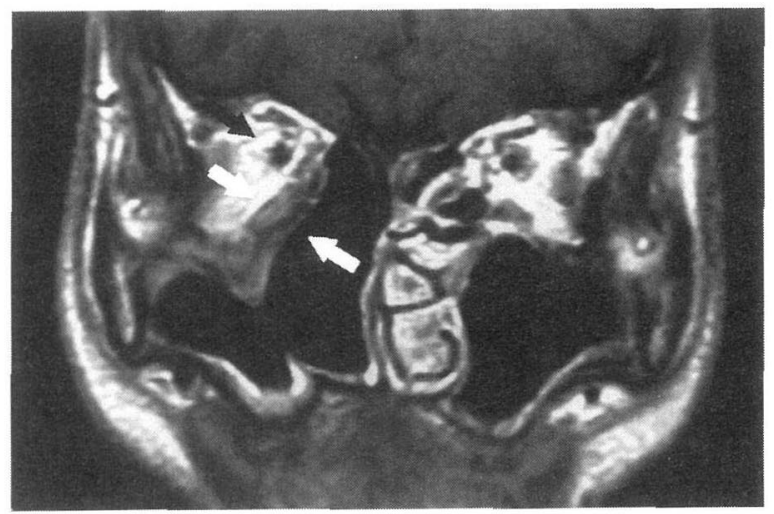

A

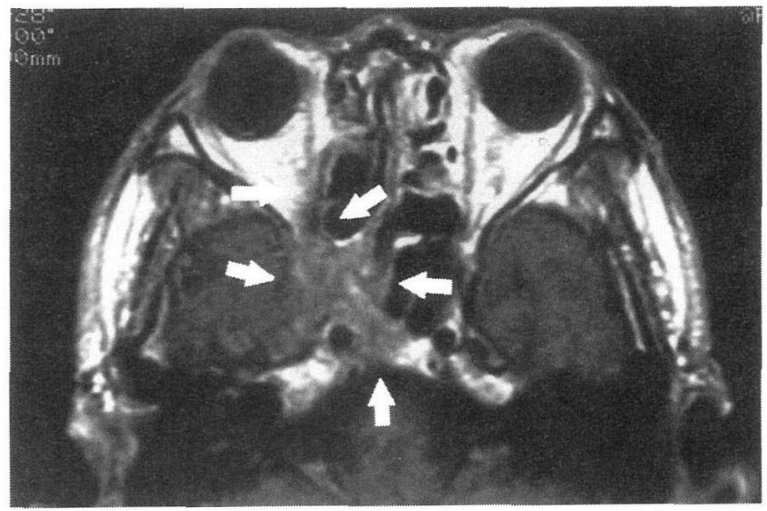

B

図 6 A. MRI 所見 (T1 強調，Gd-DTPA 投与後)。眼窩内に陰影(〔) 認める. 視神経 $(\hookleftarrow)$ の圧排偏位は改善している.

B. A と同条件. 篩骨洞, 眼尖部, 海綿静脈洞, 中頭蓋窩に連続する陰影を依然認めるが，治療前に比べ縮小して いる(け). 
表 2 本邦に掠ける過去の鼻脳型ムコール症例 $*(1)$

\begin{tabular}{|c|c|c|c|c|c|c|c|c|c|}
\hline No & 報告年 & 報告者 & 年齢 & 性別 & 基 礎 疾 患 & 術*(2) & 抗 真 菌 剂*(3) & $\begin{array}{l}\text { 生存中の台 } \\
\text { בニル症の } \\
\text { 診断*(4) }\end{array}$ & 転帰 \\
\hline $1^{*(5)}$ & 1963 & 須賀ら ${ }^{8)}$ & 38 & 女 & $\begin{array}{l}\text { Banti 症候群 } \\
\text { 無顆粒球症 }\end{array}$ & & & 無 & 死亡 \\
\hline 2 & 1969 & 関谷ら9) & 54 & 女 & なし & 開頭術 & & 有 & 死亡 \\
\hline 3 & 1972 & 徐ら ${ }^{10)}$ & 43 & 男 & 肺癌, 睡眠剤中毒 & & & 無 & 死亡 \\
\hline 4 & 1974 & 柴田 $5^{11)}$ & 51 & 男 & 糖尿病 & & & 無 & 死亡 \\
\hline 5 & 1976 & 犬山ら & 64 & 女 & 糖尿病疑い & & & 無 & 死亡 \\
\hline 6 & 1976 & 犬山ら & 30 & 男 & 糖尿病 & 右副鼻腔根本術 & AMPH 静注 & 有 & 生存 \\
\hline 7 & 1982 & 市村 54) & 45 & 女 & 糖尿病 & 左上靧洞篩骨洞根本術 & AMPH 静注 & 有 & 死亡 \\
\hline 8 & 1982 & 市村 54) & 77 & 女 & 糖尿病 & 左上類洞穿刺洗浄 & & 有 & 生存 \\
\hline 9 & 1985 & 佐伯ら ${ }^{14)}$ & 49 & 男 & 糖尿病 & 篩骨洞開放術 & AMPH 静注 & 有 & 生存 \\
\hline 10 & 1985 & 辺土名ら ${ }^{15)}$ & 37 & 男 & 糖尿病 & 左上靧洞根本術 & flucytosine 内服 & 有 & 生存 \\
\hline 11 & 1986 & 原ら ${ }^{16)}$ & 43 & 女 & 糖尿病 & & & 無 & 死亡 \\
\hline 12 & 1986 & 小川ら ${ }^{17}$ & 47 & 男 & 糖尿病 & 開洞 & $\begin{array}{l}\text { AMPH 静注, } \\
\text { flucytosine 内服 }\end{array}$ & 有 & 生存 \\
\hline 13 & 1989 & 寺邑ら ${ }^{18)}$ & 80 & 男 & 糖尿病 & 右上䫁洞根本術 & miconazole & 有 & 死亡 \\
\hline 14 & 1989 & 石田ら6) & 71 & 男 & 糖尿病, 膀朕腫瘍 & 両側副鼻腔根本術 & AMPH 静注 & 有 & 死亡 \\
\hline 15 & 1989 & 石田ら6) & 43 & 女 & 糖尿病 & & & 無 & 死亡 \\
\hline 16 & 1989 & 長江ら ${ }^{19)}$ & 36 & 女 & 急性骨髄性白血病 & 左上靧洞篩骨洞根本術 & AMPH 局所使用 & 有 & 死亡 \\
\hline 17 & 1990 & 林ら 20$)$ & 60 & 男 & なし & & & 無 & 死亡 \\
\hline 18 & 1992 & 大出ら ${ }^{21)}$ & 55 & 男 & $\begin{array}{l}\text { 糖尿病, } \\
\text { 慢性督不全 }\end{array}$ & & AMPH 静注 & 有 & 生存 \\
\hline 19 & 1993 & Ochiai $5^{22)}$ & 74 & 男 & 糖尿病 & 前頭下開頭 & AMPH 静注 & 有 & 死亡 \\
\hline 20 & 1993 & 林 $5^{23)}$ & 42 & 男 & 糖尿病, 肝硬変 & $\begin{array}{l}\text { 齈外饰笁骨洞根本術, } \\
\text { 容除術 }\end{array}$ & AMPH 静注 & 有 & 生存 \\
\hline 21 & 1997 & 本症例 & 68 & 男 & なし & 右副鼻腔根本術 & AMPH 静注 & 有 & 生存 \\
\hline
\end{tabular}

*(1) 口蓋潰瘍を形成しても眼窩や頭蓋内の病変がないものは除いた。 また，血行性に直接脳内に病変を作ったと考えられるものは 除いた.

*(2) 症例が受けた外科的治療を記載した。*(3) 症例が受けた抗真菌剤による治療を記載した。*(4) 生存中にムコール症と診断されて いたかを記載した。*(5) 肺型ムュール症を併発した。

として使用する場合は問題ないが，血管内投与する場合， 腎障害, 貧血 (正色素性, 正細胞性), 発熱, 悪寒, 戦傈, 血栓性静脈炎といった副作用が高率に出現する．特に腎 障害については，静注患者の約 $80 \%$ に起こるとされ，そ れが原因で死の転帰をとることもある．静注の際は，血 中尿素窒素, クレアチニン， クレアチニンクリアランス のモニターを定期的に行い，異常があれば，減量，ある いは隔日投与にする.Pillsbury ら ${ }^{25)}$ は，血中尿素窒素 が $50 \mathrm{mg} / \mathrm{d} 1$ 以上，またはクレアチニンが $3.0 \mathrm{mg} / \mathrm{dl}$ 以
上またはクレアチニンクリアランスが $30 \mathrm{ml} /$ 分以下 になれば静注を見合わせるべきだとしている．可能であ れば維持量 $1 \mathrm{mg} / \mathrm{kg}$ / 日で連日静注し, 総量 $2.5 \sim 4.0 \mathrm{~g}$ まで投与するのが一般的だが, 熱型, 創の治癒状態, 菌 検で陰性, 白血球数の正常化などの臨床症状や所見が中 止の基準となる7). 今回, 局所により高濃度で薬剤を作 用させ，しかも全身的副作用を少なくしようとする考兄 から, AMPH の24時間持続動注を行ったが, 血管痛の ためわずか 5 日間で $28 \mathrm{mg}$ の投与しかできずその効果 
は評価できなかった．今回の症例では, 当初より視機能 は障害されていなかったため, 眼球摘出は行わなかった が，治療により，治療前に認められた眼球運動障害も消 失し，後遺症となる眼症状を残さなかった。治療開始時 に視機能が残存する場合, 眼球摘出については慎重に決 めるべきと思われる．治療終了より 2 年を経て再発した といら報告 ${ }^{26)}$ もり，長期の経過観察が必要と思われ る.

予後については, AMPH の登場にて改善したが，い ぜん不良である．本邦での RCM 報告例20例と，自験例 1 例を加えた21例を表 2 に示寸. 男性13例, 女性 8 例, 平均年龄は 53 歳で, 全体の死亡率は, $62 \%$ でる. 生存 中にムュール症と診断されたものでも $36 \%(5 / 14)$ の死亡 率で予後不良の疾患であるといえる。 しかし，死亡率は 1970年代までの報告で83\% (5/6)，80年代で56\% (5/9)， 90年代で $50 \%(3 / 6)$ となって抑り, 予後は改善傾向にあ るのがわかる. Blitzer ら7は, 白血病などの悪性疾患 を合併したものは特に悪く生存率 $20 \%$, 糖尿病を合併し たものは生存率 $60 \%$, 基礎疾患を持たないものは生存率 $75 \%$ として扣り, 基礎疾患を持たないものの生存率が高 い.しかし基礎疾患を持たない健康人でも死亡すること があり, 本邦でも症例 $2 ， 17$ は基礎疾患なく死亡してい る. 今回の症例で救命できたのは, 早期の診断, 治療が できたこと，扣よび基礎疾患が無く，免疫機能が正常で あったことが考兄られる. しかし, 健康人での死亡例の 報告もあることから，もし適切な治療が行われなければ， 全身に播種, 内頸動脈の梗塞などにより不幸な転帰をと っていたとも考えられる.

\section{まとめ}

(1)健康人に発症した RCM で, 手術と AMPH の投与 により救命した 1 例を経験したので報告した. 眼球摘出 は行わず，治療後の後遺症として眼症状を残さなかった。

(2)発症の誘因となる生活歴を認めた.

(3)AMPH の副作用として腎障害を認め, 休薬, 隔日 投与を行い総量 $899 \mathrm{mg}$ を血管内投与した.

(4)本邦での過去の RCM 報告例を調べても， RCM の 予後は不良で, 診断, 治療を受けてもな技 $38 \%$ の死亡率 であった。

(5)健康人の RCM は，糖尿病などの基礎疾患をもった 症例上りは予後はよいが，死亡することもあり，早期診 断, 早期治療が望まれる.

\section{参考文献}

1 ) 夜陣紘治 : 副鼻腔真菌症. 日耳鼻専門医通信 $38: 8 \sim 9,25$, 1994.

2 ) Abramson E, Wilson D and Arky RA : Rhinocerebral phycomycosis in association with diabetic ketoacidosis. Ann Intern Med 66 : 735 742, 1967.

3 ) 吉野清美, 中島博昭, 中島幸洋, 他: 鼻副鼻腔真菌症の臨 床的観察 一副鼻腔真菌症 8 症例一. 耳鼻臨床 補 $9: 168 \sim$ $175,1987$.

4 ）市村恵一, 星野知之, 矢野, 純, 他：鼻副鼻腔真菌症と眼 合併症. 耳喉 $54: 57 \sim 63,1982$.

5 ) Hora JF : Primary aspergillosis of the paranasal sinuses and associated areas. Laryngoscope $75: 768 \sim 773,1965$.

6 ) 石田 稔, 野入輝久, 田矢值三, 他: 鼻副鼻腔ムコール症. 日耳鼻 $92: 21 \sim 27,1989$.

7 ) Blitzer A, Lawson W, Meyers BR, et al : Patient survival factors in paranasal sinus mucormycosis. Laryngoscope $90: 635 \sim 648,1980$.

8 ）須賀純之助, 羽飼 昭, 加島 弘 : 眼症状を伴った汎発性 ムコール菌症の 1 剖検例. 臨眼 $17: 365 \sim 373,1963$.

9 ) 関谷透, 山田隆志, 原八洲雄, 他：めまい症例 (Cerebral Mucormycosis)。耳喉 41 : 147 157, 1969.

10）徐 勝常, 吉村 康, 奥野一裕, 他: 肺癌に随伴した脳ム コール症の 1 剖検例. 臨床と研究 $49: 3470 \sim 3471, ; 1972$.

11）柴田温三, 高梘健介, 富田明夫, 他 : 糖尿病性ヶトアシドー シスに合併した Rhinocerebral Mucormycosis $の ~ 1$ 剖検例. 内科 $33: 180 \sim 183,1974$.

12）犬山征夫, 小津雷助, 浅岡一之, 他 : Rhinocerebral mucormycosis の一剖検例拉よび本疾患に関する統計的観察. 耳鼻臨床 $69: 907 \sim 917,1976$.

13）犬山征夫, 高崎 敬, 犬山幸子, 他 : 糖尿病に合併した Rhinocerebral mucormycosis $の 1$ 例. 耳喉 $47: 345 \sim 349$, 1976.

14）佐伯哲郎, 大塚幸之, 伊藤新郎, 他 : 頭蓋内進展をきたし た鼻腔内ムコール症の例. 日鼻誌 $24: 128 \sim 129,1985$.

15）辺土名仁，竹生田勝次，石川紀彦，他 : 上罘腫瘍を思わせ た副鼻腔真菌症. 耳喉 $57: 405 \sim 410,1985$.

16）原斉, 矢倉宏祐, 本田繁則, 他: 副鼻腔炎から激烈な 頭蓋内感染症を発症した脳型ムュール症の 1 剖検例. 日内 会誌 $75: 824,1986$.

17）小川 郁, 岡本亮二, 川谷敦子, 他 : Rhinocerebral mucormycosis の 1 症例. 日耳鼻 $89: 916,1986$.

18）寺邑公子, 矢野一彦：上頱洞真菌症にて死亡した 1 症例. 埼玉県医学会雑誌 $24: 809 \sim 811,1989$.

19）長江大介, 馬場廣太郎, 後藤治典, 他 : 副鼻腔ムュール症 の 1 症例. 耳喉頭頸 $61: 201 \sim 205,1989$.

20）林 明俊, 牧野浩二, 森満 保, 他: Rhinocerebral mucormycosis の一症例と文献的考察. 日耳鼻 $93: 2014 \sim 2021$, 
1990.

21）大出尚郎, 鴨下 泉, 小川葉子, 他 : 眼症状を伴った鼻脳 ムコール症の 1 例. 眼紀 $43: 507 \sim 511,1992$.

22) Ochiai $H$, Iseda $T$, Miyahara $S$, et al : Rhinocerebral mucormycosis. Neurol Med Chir Tokyo $33: 373 \sim 376$, 1993.

23）林 英憲, 増田 環, 林 亜紀, 他 : 眼窩内容除去術を行 った眼窩ムコール症の 1 例. 眼紀 $44: 1193 \sim 1199,1993$.

24) 久米 光, 奥平雅彦, 八尾和雄: 藻菌類. 化学療法の領域 3: 700 706, 1987.

25) Pillsbury $\mathrm{HC}$ and Fischer ND : Rhinocerebral mucor- mycosis. Arch Otolaryngol $103: 600 \sim 604,1977$.

26) Nussbaum ES and Hall WA : Rhinocerebral mucormycosis : changing patterns of disease. Surg Neurol 41 : $152 \sim 156,1994$.

$$
\left.\begin{array}{l}
\text { 原稿受付 : 平成 } 9 \text { 年 } 4 \text { 月 } 23 \text { 日 } \\
\text { 原稿採択 : 平成 } 9 \text { 年 } 5 \text { 月 } 28 \text { 日 } \\
\text { 別刷請求先 : 花満雅一 } \\
\text { 干 } 627 \text { 京都府中郡峰山町杉谷 } 158-1 \\
\text { 丹後中央病院耳鼻咽喉科 }
\end{array}\right)
$$

